\title{
ゾーン精製で高純度化した原料による $\mathrm{p}$ 型 InSb 蒸着薄膜の生成と電気的特性
}

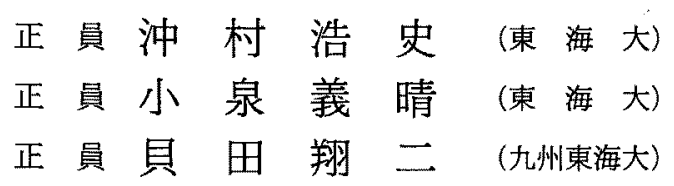

\section{Preparation of $\mathrm{p}$-InSb Thin Films using Zone Refined Source Materials and their Electrical Properties}

\author{
Hiroshi Okimura, Member, Yoshiharu Koizumi, Member (Tokai University), Shoji Kaida, Member \\ (Kyushu Tokai University)
}

\begin{abstract}
InSb thin films were prepared on mica substrates by conventional vacuum evaporation with suitable temperature programming for source and substrate, and their electrical properties were investigated. Though the deposited films had InSb-In structure due to the loss of antimony during evaporation, the films prepared by zone refined InSb source material with lower deposition rate obtained $\mathrm{p}$-type conduction. The films showed dendritic crystal regrowth, and obtained high mobilities of electron and hole respectively. The acceptor impurities were the residual impurities originally included in In and Sb source materials which had high segregation constants during the zone refining process. The $\mathrm{p}$-InSb films showed $n$-type conduction at room temperature range, and the high electron mobility was available for many practical devices.
\end{abstract}

キーワード：薄膜，InSb 薄膜， $\mathrm{p}-\mathrm{InSb} ，$ ホール効果，真空蒸着

\section{1. まえがき}

各種の産業機器のエレクトロニクス化や，情報処理に伴 う多量の情報信号を高速で処理するため，超小型で高性能 の電子デバイスの開発が進められている。更に多機能性, 多重処理に対応できる集積度の高い多層構造の集積回路の 開発には，高い電子移動度をもつ薄膜やそのデバイスの開 発が重要である。

最も高い電子移動度をもつInSb は, この点で大きな可 能性をっている。一般に化合物半導体の薄膜は, 構成元 素の蒸気圧の差により組成比がずれやすい。このため, 生 成した膜は結晶性の程度が低く, キャリヤの移動度も小さ い。そこで, InSb 薄膜の生成には構成元素の化学量論的 組成比を保つため, MBE 法やMOCVD法などの生成 法(i) (5) が利用されている。この場合, 高い電子移動度を もつ薄膜のほとんどは, 半導体単結晶基板上にエピタキシ ヤル成長をさせて得られている。しかし, 絶縁性基板上に 生成された低価格の InSb 薄膜は, 特に磁気センサの量産 用などに依然大きな必要性をもっている。

$\mathrm{InSb}$ の融点は $525^{\circ} \mathrm{C}$ と低いため, InSb 薄膜の生成には 量産に適した簡易な真空蒸着法 ${ }^{(6)}(9)$ が使用できる。しか しこの生成法では, 蒸気圧の高い Sb が基板から再蒸発す
るため, 過剩の In が偏析・析出し, 薄膜は InSb-In の二 相構造となる。またこの Sbの不足により，一般に得られ る薄膜は $\mathrm{n}$ 型の電気伝導を示す。

多くの電子デバイスは $\mathrm{n}$ 型だけでなく $\mathrm{p}$ 型も必要とし ており，InSbでは通常 $\mathrm{Cu}$ や Be などのアクセプタ不純物 を添加することによって p 型薄膜(10) (14)を得ている。ま た，過剩のアニオン原子がアクセプタとなることを利用す るよう $\mathrm{Sb}$ を補充しながら真空蒸着する方法で $\mathrm{p}$ 型薄膜を 得ることも試みられている(15)。一方ゾーン精製法によ るInSb 単結晶の生成中, バルクの頭部の高純度部分で $\mathrm{p}$ 型 InSb になるという報告(16) を検討すれば，蒸着条件によ っては無添加の $\mathrm{InSb}$ の蒸発源で $\mathrm{p}$ 型の薄膜が得られる可 能性がある。そこで本研究では, 無添加の InSb の蒸発源 を用い, 一般の真空蒸着装置により得られる $\mathrm{p}$ 型薄膜の 生成条件と電気的特性について報告する。

\section{InSb 薄膜の生成}

99.9999\%（6ナイン）のInと Sbを混合し, 高純度水 素中で融解・化合させた後, 数回ゾーン精製を行って得ら れた高純度 InSb 多結晶を蒸発源の原料とし, Mo ヒー夕 により蒸着させた。基板はマイカを用い, 油拡散ポンプに ょり約 $2 \times 10^{-5}$ Torr に保った真空中で蒸着を行った。蒸 
着時の基板温度は高いほうが結晶粒子を大きく成長させ, 高い電子移動度の膜を得るのに適している。しかしInよ り蒸気圧が高い Sb の再蒸発も大きくなるので, 蒸着中基 板温度と蒸発源温度をともに上昇させる二重温度プログラ ム法[文献 ( 9 )の Fig. 1]を標準プログラム Sとした。次 に,この標準プログラム $\mathrm{S}$ を種々に変化させ $\mathrm{p}$ 型の薄膜 の生成できる可能性を調べたところ,

（1）蒸発源となるIn と Sbを混合融解し化合させる 前に，それぞれ真空（約 $10^{-3}$ Torr）中で融解させ て揮発性の不純物を少なくしたのち，両者をそのま ま同一のボートに乗せて融解し，ゾーン精製を行っ て純度を上げるとともに化合させて InSbの結晶と する。

（2） InSb 多結晶の生成時のゾーン精製回数を，10 回 以上に增やす。

（3）基板および蒸発源の最高到達温度をやや低くし， 蒸着速度を遅くする。

の条件で $\mathrm{p}$ 型の薄膜が得られることがわかった。そこで, この代表的な温度プログラムを図 1 に示す。ここで,

（i） プログラム S：最高到達基板温度および蒸発源温 度はそれぞれ $440^{\circ} \mathrm{C}, 1,100^{\circ} \mathrm{C}$, 蒸着時間は約 20 分

(ii） プログラム $\mathrm{M}$ ：最高到達基板温度および蒸発源 温度はそれぞれ $430^{\circ} \mathrm{C}, 1,080^{\circ} \mathrm{C}$ ，蒸着時間は約 30 分

（iii） プログラム L：最高到達基板温度および蒸発源温 度はそれぞれ $420^{\circ} \mathrm{C}, 1,050^{\circ} \mathrm{C}$, 蒸着時間は約 40 分 として, 最高到達基板温度および蒸発源温度を下げる代わ りに蒸着時間を長くするプログラムとした。得られた膜の

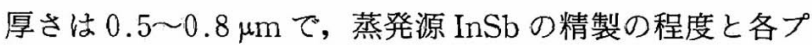
ログラムの組合せに従って生成される各薄膜の電気的特性 を比較した。

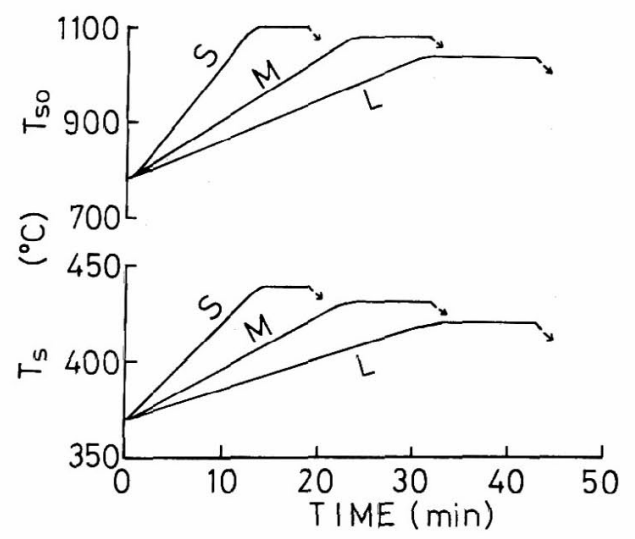

$T_{s o}$ : 蒸発源温度, $T_{s}$ : 基板温度 図中の文字はプログラムの種類を示す。

図 1 InSb 薄膜生成の温度プログラム Fig. 1. Temperature programs for source $T_{\text {so }}$ and substrate $T_{s}$.

\section{3. 実験結果と検討}

〈3・1〉薄膜の結晶成長 生成した InSb 薄膜の結晶 性を見るため，代表的な薄膜の表面写真を図 2 に示す。薄 膜はデンドライト状結晶成長をしており，どの薄膜も液滴 状の粒子をもっている。EPMA の面分析によれば，この 粒子は偏析・析出した Inである(9)。このInの偏析による 粒子密度は, 図 2 の薄膜 D (プログラムLによる) では 薄膜 A（プログラムSによる）に比較してかなり減少し ていることから見られるように，プログラム M, Lによ る薄膜において減少している。

次に図 3 に代表的な薄膜の X 線回折図を示す。どちら の回折図においてもInによる回折線が見られるが，その 強度は薄膜 Dにおいて小さく,これは図 2 の表面写真の 結果と一致している。X 線回折の結果から, 生成した薄 膜はすべて InSb-Inの 2 相構造となっている。しかしプ ログラム L による薄膜 D の InSb 相は, 次節で示すよう に p 型となっている。生成する薄膜は, 蒸着過程の初期 には蒸気圧の高い $\mathrm{Sb}$ 成分が多いが，かなりの Sb は膜表 面から再蒸発で失われてしまうので，後半はIn成分が多 い。しかし，デンドライト成長した結晶部分は全体的に化 学量論的組成に近い $\mathrm{p}$ 型薄膜となり，また失われた $\mathrm{Sb}$ に 対応するInは過剰なIn粒滴となって表面近くに析出する。
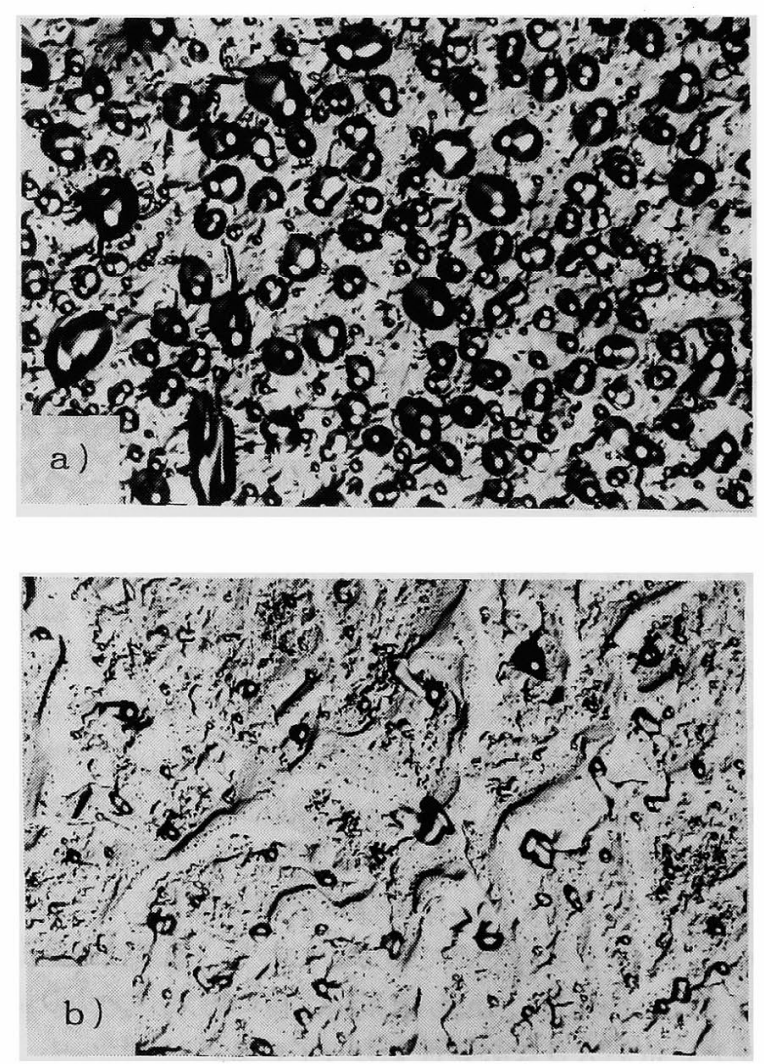

（a）薄膜 A，（b ）薄膜 D

図 $2 \mathrm{InSb}$ 薄膜表面の顕微鏡写真 $(\times 600)$

Fig. 2. Microphotographs of InSb film $(\times 600)$. 
〈3・2〉薄膜の電気的特性生成した $\mathrm{InSb}$ 薄膜は, ぞの場合も蒸着後半にデンドライト状の結晶再成長が見ら れた。このため, 室温で電子移動度 $\mu_{e}$ が $40,000 \mathrm{~cm}^{2} / \mathrm{Vs}$ 以上の $\mathrm{n}$ 型伝導を示す薄膜が得られた。

薄膜の電気的特性を調べるため, マイカ基板上で長方形 (約 $2 \times 10 \mathrm{~mm}^{2}$ ) のホール効果測定用素子を切り出し，ホ 一ル定数 $R_{H}$ 抢よび導電率 $\sigma$ について, 温度 $T$ との関係 を求めた。またホール測定にはPauw 法も用いたが，両 者の誤差は約 7\%以下であった。

図 4 に代表的な薄膜のホール定数 $R_{H}$ の温度依存性示 す。また各薄膜の精製条件は表 1 に示す。低温領域におい て $R_{H}$ の符号が逆転する $\mathrm{p}$ 型伝導特性は, 蒸発源 $\mathrm{InSb} の$

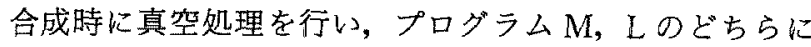
促って蒸着した薄膜においても見られ，プログラム $\mathrm{S} に$ よる薄膜では, 真空処理をしない蒸発源のInSb 結晶を用 いた薄膜では $\mathrm{n}$ 型, 真空処理をして揮発性の不純物を減 少させた原料により生成した薄膜では，低温度で $R_{H}$ の符 号の逆転は見られないものの， $R_{H}$ が減少する $\mathrm{n}, \mathrm{p}$ 領域 の混合型 (mixed) ${ }^{(17)(18)}$ が見られる。

次に, 図 5 に各薄膜の導電率 $\sigma$ の温度依存性を示す。 蒸発源の差やプログラムの違いによるのの差は小さい。 しかし，p型伝導を示す薄膜の $\sigma$ は低温度においてやや小 さくなっている。

一般に正孔密度 $\mathrm{p}$ と電子密度 $\mathrm{n}$ が同程度存在する混合 伝導では，正孔および電子の移動度をそれぞれ $\mu_{h}, \mu_{e}$ と

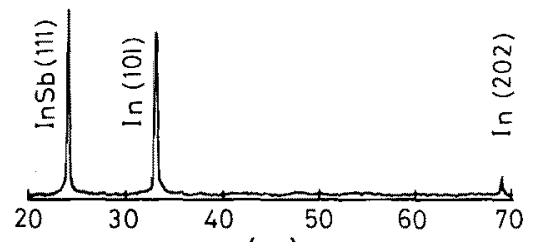

(a)

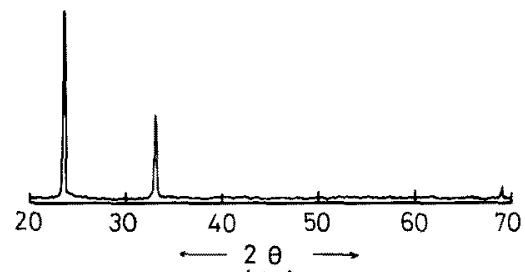

(b)

(a) 薄膜 A, (b) 薄膜 D

図 $3 \mathrm{InSb}$ 薄膜の $\mathrm{X}$ 線回折図

Fig. 3. X-ray diffraction patterns of InSb thin films.
すれば， $R_{H}$ は次のように表される。

$$
R_{H}=\frac{p \mu_{h}^{2}-n \mu_{e}^{2}}{e\left(p \mu_{h}+n \mu_{e}\right)}
$$

この式から, InSbでは $\mathrm{p}$ 型薄膜であっても, 電子移動度 が正孔移動度より約 1 桁大きいので, 室温領域の $R_{H}$ は負 となり， $\mathrm{n}$ 型電気伝導を示す。

次に窒温より温度を下げると, 温度 $T_{m} て ゙ R_{H}$ は最大值 $R_{H m}$ をとった後 $R_{H}$ は急激に隇少し，（1）式が 0 となる条 件の温度 $T_{0}$ で $R_{H}=0$ となる。更に温度を下げると $R_{H}$ は 符号を反転して正となり，その值は再び増加するが次第に 飽和する。この低温領域に扮ける符号の反転から，これら の薄膜は $\mathrm{p}$ 型となっていることがわかる。表 1 に $R_{H}$ の温 度依存性から得られる室温における各種データを示す。

図 4 のホール定数と図 5 の導電率のデータから, 各薄膜 の電気的特性を, 次の 4 種類の温度領域で調べた。

(1) 室温 $T_{r}$

(2) $R_{H}$ が最大になる温度 $T_{m}$

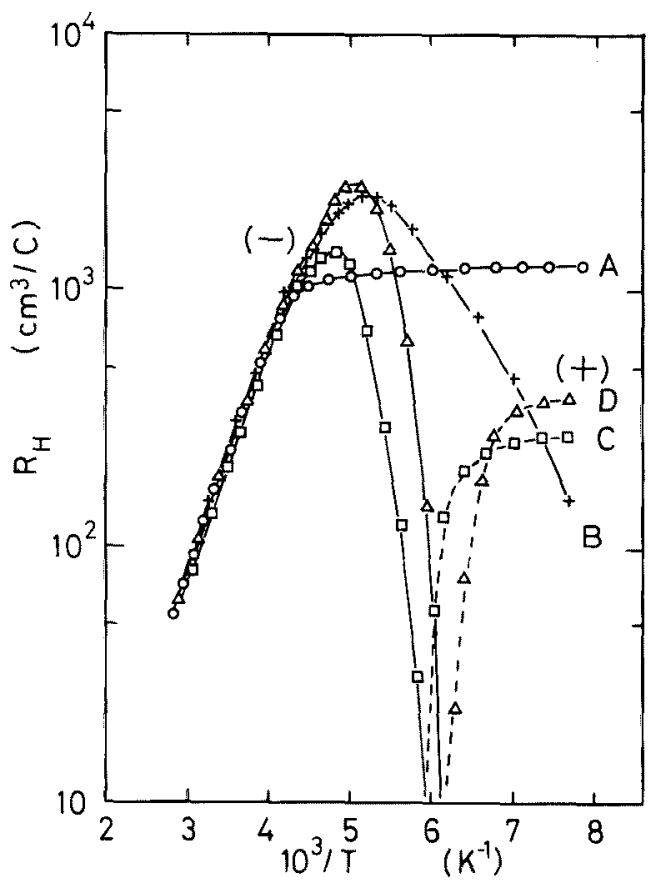

図 4 ホール定数 $R_{H}$ の温度依存性[各薄膜 (A ～D) の生成条件は表 1 に示されている]

Fig. 4. Temperature dependence of Hall constant $R_{H}$ of the films shown in Table 1.

表 1 ホール効果の測定から得られる室温における各種電気伝導データ

Table 1. Electrical parameters which were obtained from Hall effect at room temperature.

\begin{tabular}{c|c|l|c|c|c|c|c|c|c|c|c}
\hline 薄膜 & $\begin{array}{l}\text { プログ } \\
\text { ラム }\end{array}$ & 前処理 & $\begin{array}{c}\text { ソーン } \\
\text { 回数 }\end{array}$ & 伝導型 & $\begin{array}{c}R_{H r} \\
\left(\mathrm{~cm}^{9} / \mathrm{C}\right)\end{array}$ & $\begin{array}{c}\sigma_{r} \\
(\mathrm{~S} / \mathrm{cm})\end{array}$ & $\begin{array}{c}\mu_{r} \\
\left(\mathrm{~cm}^{2} / \mathrm{Vs}\right)\end{array}$ & $\begin{array}{c}n_{r} \\
\left(\mathrm{~cm}^{-3}\right)\end{array}$ & $\begin{array}{c}R_{H e} \\
\left(\mathrm{~cm}^{3} / \mathrm{C}\right)\end{array}$ & $\begin{array}{c}N_{A}-N_{n} \\
\left(\mathrm{~cm}^{-3}\right)\end{array}$ & $b$ \\
\hline $\mathrm{A}$ & $\mathrm{S}$ & ソーン精製のみ & 10 & $\mathrm{n}$ & -160 & 320 & 51,200 & $3.9 \times 10^{16}$ & $-1,200$ & $-5.2 \times 10^{15}$ & - \\
$\mathrm{B}$ & $\mathrm{S}$ & 真空処理あり & 15 & mixed & -165 & 320 & 52.800 & $3.8 \times 10^{16}$ & - & - & - \\
$\mathrm{C}$ & $\mathrm{M}$ & 真架処理あり & 15 & $\mathrm{p}$ & -140 & 340 & 51,000 & $4.5 \times 10^{16}$ & 270 & $2.3 \times 10^{16}$ & 22.8 \\
$\mathrm{D}$ & $\mathrm{L}$ & 真空処理あり & 15 & $\mathrm{p}$ & -160 & 310 & 49,600 & $3.9 \times 10^{16}$ & 380 & $1.6 \times 10^{16}$ & 29.4 \\
\hline
\end{tabular}


(3) $R_{H}=0$ となる反転温度 $T_{0}$

（4）p 型領域で $R_{H}$ が飽和した低温度領域 この場合，生成する薄膜には過剩のInが含まれているの で, 得られるデー夕は概略の值となるが, それぞれの蒸着 条件についてのキャリヤ密度と移動度を求め, $\mathrm{p}$ 型薄膜の 電気的特性を推定することができる。

（1）室温に扔ける各薄膜の電子密度 $n_{r}$, 電子移動度 $\mu_{e r}$ をそれぞれ $n=\left(e R_{H}\right)^{-1}$ おるび $\mu=R_{H} \sigma$ の式より求め た。得られた $n_{r}$ および $\mu_{e r}$ を，表1に示す。 $n_{r}$ は $3.5 \sim 4.5 \times 10^{16} \mathrm{~cm}^{-3}$ で，これまでの報告值（1.7〜3.1× $\left.10^{16} \mathrm{~cm}^{-3}\right)^{(1)(3)(4)}$ よりやや大きい。一方, 電子移動度 $\mu_{\text {er }}$ は $50,000 \mathrm{~cm}^{2} / \mathrm{Vs}$ 台付近にあるが，不純物の多いと見られる 蒸発源による薄膜においてはやや小さかった。次に不純物 密度 $N_{A}-N_{D}$ は，低温（110～120 K）の涸渴領域に扔ける ホール定数 $R_{H e}$ から得られ，表 1 に示す。 $\mathrm{p}$ 型薄膜の $N_{A}-$

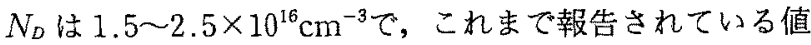
より少なかった $\left(6 \times 10^{16} \mathrm{~cm}^{-3} \text { 以上 }\right)^{(10)(11) 。 ま た ~} N_{A}-N_{D}$ が 得られるのは完全に $\mathrm{p}$ 型となっている薄膜についてであ って, 薄膜 B では反転温度が測定筫聿より低温度部にあ るため,この測定では求められない。またこのことは, 薄

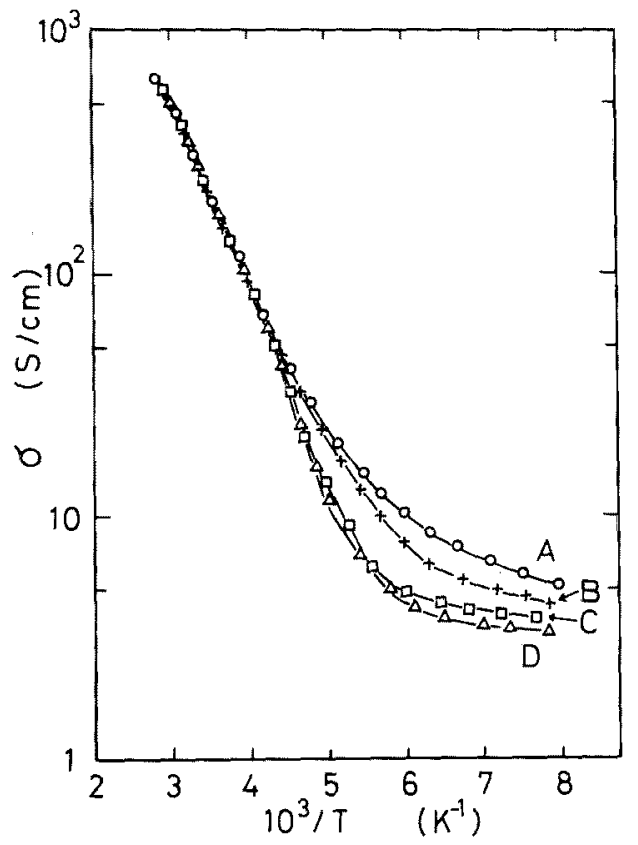

図 5 導電率 $\sigma$ 温度依存性 (各薄膜 $(A \sim D)$ ) 生成条件は表 1 に示されている]

Fig. 5. Temperature dependence of conductivity.
膜がかなり弱い $\mathrm{p}$ 型，あるいは $\mathrm{p}, \mathrm{n}$ 混合型になっている ことを示す。

（2） $R_{H}$ が最大值をとる温度 $T_{m}$ に招けるホール定数 $R_{H m}$ と導電率 $\sigma_{m}$ の值加ら, 電子移動度と正孔移動度の比 $b$, 電子移動度 $\mu_{\mathrm{em}}$, 電子密度 $n_{m}$ が得られる。電子移動 度と正孔移動度の比 $b\left(=\mu_{e} / \mu_{n}\right)$ は, $R_{H m}$ と涸渴領域にお ける $R_{H e}$ から次式(10)より求められ，表 1 に示す。

$$
\frac{R_{H m}}{R_{H e}}=-\frac{(b-1)^{2}}{4 b}
$$

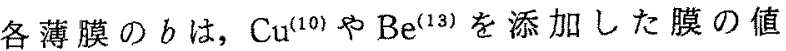
$(24 \sim 32)$ の範囲内にあり, Sb 添加の膜ともほほ同程度で ある。

この $T_{m}$ に扔ける電子密度 $n_{m}$ は, $\mathrm{p}$ 型半導体では不純 物密度を $\left(N_{A}-N_{D}\right), p=\left(N_{A}-N_{D}\right)+n$, および(1) 式で, $d R_{H} / d n=0$ として得られる次式より求められる。

$$
n_{m}=\frac{N_{A}-N_{D}}{b-1}
$$

電子および正孔の密度, $n_{m}$ と $p_{m}\left[=\left(N_{A}-N_{D}\right)+n_{m}\right] の$ 值をそれそれれ表 2 に示す。また $n_{m}$ と $p_{m}$ の積から真性キ ヤリヤ密度 $n_{i}$ が求められる。真空蒸着による薄膜は多結 晶膜で, 格子欠陷に由来するキャリヤ密度の増加があるた め, 得られた $n_{i}$ は $5 \times 10^{15} \mathrm{~cm}^{-3}$ の範囲内にあり, 牥ず れもバルク単結晶の值 ${ }^{(19)}\left(1 \sim 3 \times 10^{15} \mathrm{~cm}^{-3}\right)$ より大きかっ to

温度 $T_{m} に$ にるる電子移動度 $\mu_{e m}$, 正孔移動度 $\mu_{n m}$ は導 電率 $\sigma_{m}$ 加ら計算でき，それぞれ表 2 に示す。この場合 $\mu_{h m}$ は次式(10) から，また $\mu_{e m}$ 移動度比 $b$ が温度に依存 しないとして求めた。

$$
\mu_{h m}=\frac{\sigma_{m}}{e\left\{n_{m}(b+1)+\left(N_{A}-N_{D}\right)\right\}}
$$

得られた $\mu_{e m}$ は室温に抬ける $\mu_{e r}$ より大きいが，これは $T_{m}$ が格子散乱の減少で InSb 薄膜の移動度が最大を示す 付近にあるからである。

正孔移動度 $\mu_{h m}$ は, バルク単結晶の值 (19) より小さい。 しかし薄膜についての他の報告值 ${ }^{(10)}$ よりやや大きいが, これは本生成法による薄膜の結晶化の程度が大きいことに よる。

（3） $\mathrm{p}$ 型薄膜のホール定数は, 反転温度 $T_{0}$ で 0 とな る。この $T_{0}$ は，高純度の薄膜では高温度側に移動するこ とが図4よりわかる(15)。この $T_{0}$ におけるキャリヤ密度と 移動度は，このときの導電率 $\sigma_{0}$ と不純物密度 $N_{A}-N_{D}$ か ら, また電子密度 $n_{0}$ は (1) 式で $R_{H}=0$ の条件から次式に より求められる。

表 $2 R_{H}$ が最大となる温度 $T_{m}$ における各種電気伝導デー夕

Table 2. Electrical parameters of InSb films at temperature $T_{m}$.

\begin{tabular}{c|c|c|c|c|c|c|c|c|c}
\hline 薄膜 & $\begin{array}{c}\text { プログ } \\
\text { ラム }\end{array}$ & 公導型 & $\begin{array}{c}T_{m} \\
(\mathrm{~K})\end{array}$ & $\begin{array}{c}R_{H m} \\
\left(\mathrm{~cm}^{3} / \mathrm{C}\right)\end{array}$ & $\begin{array}{c}\sigma_{m} \\
(\mathrm{~S} / \mathrm{cm})\end{array}$ & $\begin{array}{c}n_{m} \\
\left(\mathrm{~cm}^{-3}\right)\end{array}$ & $\begin{array}{c}p_{m} \\
\left(\mathrm{~cm}^{-3}\right)\end{array}$ & $\begin{array}{c}\mu_{\text {em }} \\
\left(\mathrm{cm}^{2} / \mathrm{Vs}\right)\end{array}$ & $\begin{array}{c}\mu_{h m} \\
\left(\mathrm{~cm}^{2} / \mathrm{Vs}\right)\end{array}$ \\
\hline $\mathrm{B}$ & $\mathrm{S}$ & mixed & 190 & $-2,400$ & 15 & - & - & - & - \\
$\mathrm{C}$ & $\mathrm{M}$ & $\mathrm{p}$ & 210 & $-1,400$ & 18 & $1.1 \times 10^{15}$ & $2.4 \times 10^{16}$ & 54,700 & 2,400 \\
$\mathrm{D}$ & $\mathrm{L}$ & $\mathrm{p}$ & 200 & $-2,600$ & 13 & $5.6 \times 10^{14}$ & $1.7 \times 10^{16}$ & 72,300 & 2,460 \\
\hline
\end{tabular}


表 $3 R_{H}=0$ となる温度 $T_{0}$ における各種電気伝導データ

Table 3. Electrical parameters of InSb films at temperature $T_{0}$.

\begin{tabular}{c|c|c|c|c|c|c|c|c}
\hline 薄膜 & $\begin{array}{c}\text { プログ } \\
\text { ラム }\end{array}$ & 伝導型 & $\begin{array}{c}T_{0} \\
(\mathrm{~K})\end{array}$ & $\begin{array}{c}\sigma_{0} \\
(\mathrm{~S} / \mathrm{cm})\end{array}$ & $\begin{array}{c}n_{0} \\
\left(\mathrm{~cm}^{-3}\right)\end{array}$ & $\begin{array}{c}p_{0} \\
\left(\mathrm{~cm}^{-3}\right)\end{array}$ & $\begin{array}{c}\mu_{e 0} \\
\left(\mathrm{~cm}^{2} / \mathrm{Vs}\right)\end{array}$ & $\begin{array}{c}\mu_{h 0} \\
\left(\mathrm{~cm}^{2} / \mathrm{Vs}\right)\end{array}$ \\
\hline $\mathrm{B}$ & $\mathrm{S}$ & mixed & - & - & - & - & - & - \\
$\mathrm{C}$ & $\mathrm{M}$ & $\mathrm{p}$ & 170 & 5.0 & $4.4 \times 10^{13}$ & $2.3 \times 10^{16}$ & 30,000 & 1,320 \\
$\mathrm{D}$ & $\mathrm{L}$ & $\mathrm{p}$ & 163 & 4.3 & $1.9 \times 10^{13}$ & $1.6 \times 10^{16}$ & 46,500 & 1,580 \\
\hline
\end{tabular}

$$
n_{0}=\frac{N_{A}-N_{D}}{b^{2}-1}
$$

また電子移動度 $\mu_{e 0}$ は $\sigma_{0}$ と（5)式から得られ，次式よ り求めることができる。

$$
\mu_{e 0}=\frac{\sigma_{0}}{e n_{0}(b+1)}
$$

反転温度 $T_{0}$ における, 電子密度 $n_{0}$ および正孔密度 $p_{0}$ の値を, 移動度比 $b$ が温度に依存しないとして計算した 結果, 電子密度 $n_{0}$ は $10^{13} \mathrm{~cm}^{-3}$ の桁にあり, また $p_{0}$ は表 3 に示すように $\left(N_{A}-N_{D}\right)$ おちよび $p_{m}$ の值と同程度である。ま た $T_{0}$ に打ける電子移動度 $\mu_{e 0}$ と正孔移動度 $\mu_{h 0}$ を, それ ぞれ表 3 に示す。電子密度と同様に, 正孔移動度も低温で 減少することがわかる。

次に図 4 から見られるように，ゾーン精製により純度を 上げた蒸発源で標準プログラムSに従って蒸着された薄 膜では, 温度の減少につれてホール定数が一定でなく, 徐々に減少する特性をもつ場合がある。この薄膜 B の $R_{H}$ の符号の逆転は，この測定温度範囲では見られない。この $R_{H}$ の減少は正孔の存在が無視できず，かなりの低温度領 域で符号が逆転するか，または部分的に $\mathrm{n}$ 型領域に $\mathrm{p}$ 型 領域が混在している $\mathrm{p}, \mathrm{n}$ 混合型の伝導(17)(18) となってい ることも考えられるが，この $R_{H}$ が温度とともに減少する 電気伝導は，ゾーン精製で純度を上げた InSbで生成した 薄膜で極めてひんぱんに見られる。

以上の結果から，真空中で融解した In $\mathrm{Sb}$ を蒸発源 として生成した薄膜が完全な $\mathrm{p}$ 型となり，真空中処理を 行わない膜は極めて弱い $\mathrm{p}$ 型あるいは $\mathrm{p}, \mathrm{n}$ 混合型の薄膜 となった。これは $99.9999 \%$ の Inおび Sb中に含まれて

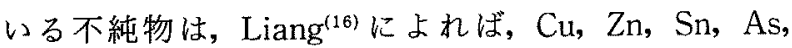
$\mathrm{Al}, \mathrm{Ga}, \mathrm{S}, \mathrm{Se}, \mathrm{Te}, \mathrm{Cd}, \mathrm{Si}, \mathrm{Mg}$ などで, 特に 10 回以 上のゾーン精製でも除去できない偏析係数 $k$ が 1 に近い 不純物は $\mathrm{Zn}(k=2.3), \mathrm{Cd}(0.26), \mathrm{Se}(0.35), \mathrm{Te}(\sim 1)$, $\mathrm{As}$ (5.4)などであると報告している。このため, $\mathrm{Zn} や \mathrm{Cd}$ がアクセプタ不純物となって InSbに残るため，生成した 薄膜の基本部分に $\mathrm{p}$ 型領域が生じるものと考えられる。 また Seや Sなどの蒸気圧の高い,ドナーとなる可能性の ある不純物が InSb の化合前に真空処理で除去されること も，無添加の InSb 蒸発源により $\mathrm{p}$ 型薄膜が生成できるこ との原因であると考えられる。

本研究で生成した InSb 蒸着薄膜は, InSb-Inの二相構 造となっている。しかし，高純度の InSb 蒸発源でプログ ラム $\mathrm{M}$ および Lにより生成した薄膜の InSb 相は，p型
の薄膜となっており, 移動度も大きい $\mathrm{p}$ 型薄膜が得られ る。この InSb 薄膜では $\mathrm{p}$ 型であっても移動度の比 $b$ が 1 桁以上大きいので，To以上温度領域では $\mathrm{n}$ 型電気伝導 を示す。また，偏析係数の関係でゾーン精製で除けない不 純物以外は除去された高純度の薄膜になっているので, 室 温付近で使用すれば，その高い電子移動度を用いる実用の 半導体薄膜デバイスに利用できる。

\section{4.あとがき}

化合物の化学量論的組成を維持し，析出In量を減らす ため蒸着速度を遅くしたプラグラム $\mathrm{M}$ ，Lに従って，ゾ ーン精製により純度を上げた InSb 蒸発源により簡易な真 空蒸着装置を用いて生成した薄膜は，p型の伝導特性を示 すことがわかった。この方法による薄膜では異種の不純物 を添加せず，構成原子のバランスの差とゾーン精製で除去 できないアクセプタ不純物と，また点着後半に生じるデン ドライト状の結晶成長を利用しているため, キャリヤの移 動度の低下も小さい $\mathrm{p}$ 型薄膜となった。また，この膜の 電子移動度と正孔移動度の比 $b$ も 1 桁以上大きいので, 室温領域で高い電子移動度を利用できることがわかった。

終りに，日ごろ御指導をいただいている酒井善雄東京工 業大学名誉教授および本研究に種々の御意見をいただいた 静岡大学大下正秀教授に感謝の意を表す次第である。ま た，本実験に協力された卒業生 平賀元文，林 省三氏に 謝意を表したい。

(平成 8 年 4 月 26 日受付, 同 8 年 7 月 24 日再受付)

\section{文献}

(1) J. I. Chyi, S. Kalem, N. S. Kumar, C. W. Litton \& H. Morkoc: Appl. Phys. Lett, 53, 1092 (1988)

(2) S. Wood, J. Greggi, R. F. C. Farrow, W. J. Takei, F. A. Shirland \& A. J. Noreika: J. Appl. Phys., 55, 4225 (1984)

(3) J.E. Oh, P. K. Bhattacharya \& S. Tsukamoto: ibid., 66, 3618 (1989)

(4) J. I. Chyi, D. Biswas, S. V. Iyer, N. S. Kumar \& H. Chen: Appl. Phys. Lett., 54, 1016 (1989)

(5) P.E. Thompson, J. L. Davis \& J. Waterman: J. Appl. Phys., 69, 7166 (1991)

(6) H. Wieder \& A. Clawson: Solid-State Electron, 8, 467 (1965)

(7) N.F. Teed: ibid., 10, 1069 (1967)

(8) L.W. Chou: Thin Solid Films, 215, 188 (1992)

(9) H. Okimura, T. Matsumae \& M. Ohshita: J. Appl. Phys., 66, 4252 (1989)

(10) R. Potter \& H. Wieder: Solid-State Electron, 7, 253 (1964)

(11) C. H. Ling, J. H. Fisher \& J.C. Anderson: Thin Solid Films, 14, $267(1972)$

(12) K. V. Krishna, P. C. Mathur \& O. P. Taneja: ibid., 60, 249 (1979)

(13) A. J. Noreika, J. Greggi, Jr., W. J. Takei \& M. Fracombe : J. 
Vac. Sci. Technol., A1, 558 (1983)

(14) A. L. Dawar, O. P. Taneja, B. K. Sachar \& P. C. Mathur: J. Electro Chem. Soc., 128, 1552 (1981)

(15) H. Okimura, Y. Koizumi \& S. Kaida : Thin Solid Films, 254 169 (1995)

(16) R. K. Willardson \& H. L. Goering : Compound Semiconductors, vol. 1, Chap. 27 (1962) Reinhold, New York

(17) J. Shigeta, N. Kotera \& T. Oi : J. Appl. Phys., 47, 621 (1976)

(18) W. Hanus \& M. Oszwaldowski : Thin Solid Films, 61, 235 (1979)

(19) C. Hilsum \& A.C. Rose-Innes : Semiconducting III-V Compounds, Chap. 6 (1961) Pergamon, Oxford

沖 村浩史 (正員) 1933 年1月15日生。1958 年東京工業 大学電気工学科卒業。同年三菱油化 (株) 入社。 1960 年東京工業大学電子工学科助手。1 971 年東 海大学金属材料工学科助教授, 1973 年同教授, 現在に至る。この間, 1973 74 年, 1984 86 年 アメリカ・ノースウェスタン大学材料工学研究 所りサーチフェロー。工学博士。主として, 電 気電子材料および半導体デバイスの研究に従事。 材料科学会, SHM, 応用物理学会会員。
小泉義 晴 (正員) 1940 年 3 月 15 日生。1963 年東海大学 工学部応用理学科卒業。同年同大学工学部応用 理学科助手, 1968 年同応用物理学科講師, 同助 教授を経て, 1990 年同教授, 現在に至る。工学 博士。主として, 磁性薄膜, 磁性酸化物の物性 基礎の研究に従事。物理学会, 応用物理学会, 日本応用磁気学会会員。

貝田翔 二 (正員) 1942 年 6 月 3 日生。1977 年早稲田大学

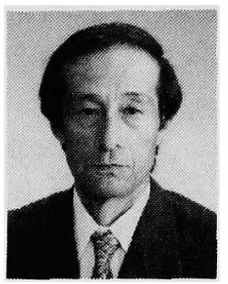
理工学研究科電気工学専攻博士課程修了。同年 九州東海大学工学部電気工学科講師, 同助教授 を経て, 1985 年同教授, 現在に至る。工学博 士。主として, 薄膜電子・磁性材料の結晶成長 の研究に従事。応用物理学会会員。 